Karol topatecki*

\title{
Discipline in Polish-Lithuanian cavalry units during battles in the early modern period ${ }^{1}$
}

https://10.1515/openms-2020-0104

Received Jul 13, 2020; accepted Sep 08, 2020

\section{Abstract:}

Keywords: articles of war, military discipline, organization of cavalry, tactics in the 16th-18th c., desertion, old-Polish art of war

The Polish and Lithuanian military in the modern period developed in a different direction from most European areas. First and foremost, it is emphasized that we did not deal with military revolution (it would be better to use the term "evolution"), which did not bring about the origins of a modern military-fiscal state on the territory of the Commonwealth ${ }^{2}$. This issue certainly requires comprehensive studies, since from at least the mid-17 ${ }^{\text {th }}$ century onwards, both on the military level as well as in the state organization, the Commonwealth coped well with strong enemies: the Teutonic Order (1519-1521), the Roman Empire (Austria) (1587-1588), the Kingdom of Sweden and the Tsardom of Moscow (15571582, 1600-1629, 1632-1635) and the Ottoman Empire (1621, 1633-1634) ${ }^{3}$. The research on transformations occurring in the $16^{\text {th }}$ century indicate crucial changes in the military, but different from those developed in Western Europe.

Among the differences it is important to name primarily the reliance on cavalry which fought with polearms and cutting weapons. Moreover, the Crown and the Grand Duchy of Lithuania lacked strongholds understood as large cities fortified with bastions ${ }^{4}$. These two elements, as well as deficiencies of the fiscal system, which were "patched" by complementing paid troops with private units, district troops and Mass Mobilization",

1 The article was written as part of the research project of the National Centre for Science SONATA, no. 2016/23/D/HS3/03210 titled „The military revolution as a modernization factor in the public finance and state organization of the Polish-Lithuanian state in the comparative perspective".

2 R. I. Frost, The Polish-Lithuanian Commonwealth and the „Military Revolution”, in Poland and Europe: Historical Dimensions, M.B. Biskupski, J.S. Pula (ed.), Columbia University Press, New York, 1994: 19-47. The author emphasizes in particular the unused chance of reforms, which was connected with a huge military, political and economic crisis in the mid-17th century. R.I. Frost, Potop a teoria rewolucji militarnej, in Rzeczpospolita w latach potopu, J. Muszyńska, J. Wijaczka (ed.), Wyższa Szkoła Pedagogiczna im. Jana Kochanowskiego, Kielce, 1996: 147-165 (in Polish).

3 The issues have been described in an enormous number of monographs (in particular of the 21st c.) referring to both particular wars and single battles. However, there are no new comprehensive works. The key role is still played by two outdated works: T.M. Nowak, J. Wimmer, Historia oręża polskiego 963-1795, Wiedza Powszechna, Warszawa, 1981 (in Polish); Polskie tradycje wojskowe, t. I: Tradycje walk obronny z najazdami Niemców, Krzyżaków, Szwedów, Turków i Tatarów X-XVII, J. Sikorski (ed.), Wydawnictwo Ministerstwa Obrony Narodowej, Warszawa, 1990 (in Polish).

4 B. Dybaś, Fortece Rzeczypospolitej. Studium z dziejów budowy fortyfikacji stałych w państwie polsko-litewski w XVII wieku, Towarzystwo Naukowe w Toruniu, Toruń, 1998: 326-335 (in Polish).

5 D. Kupisz, Wojska powiatowe samorządów Małopolski i Rusi Czerwonej w latach 1572-1717, Wydawnictwo Uniwersytetu Marii Curie-Skłodowskiej, Lublin, 2008 (in Polish); D. Kupisz, Wyprawy żołnierza łanowego w Koronie w czasach Jana Kazimierza, Wydawnictwo Sejmowe, Warszawa, 2018 (in Polish).

*Corresponding author: Karol topatecki, a professor of the Faculty of History and International Relations at the University of Białystok, Poland [Email: k.lopatecki@uwb.edu.pl ORCID: https://orcid.org/0000-0002-7921-9421] 
resulted in creating a different strategy of military actions. In simple terms, achieving victory was seen in giving the enemy a battle 6 . In the context of operational actions, they attempted to control the area of the warfare, and simultaneously through destructive raids they would disorganize the enemy's defense; alternatively they applied hit-and-run tactics?. The key element was the skillful use of infantry, artillery and field fortifications in order to maximize the cavalry's combat capability ${ }^{8}$.

Consequently, battle was of different importance and meaning than in Western Europe ${ }^{9}$. It was conducted in an incomparably more dynamic way, with the use of the breaking force of heavy cavalry and attempts at outflanking by light cavalry units ${ }^{10}$. In this article I analyze the ways of imposing military discipline upon the troops during a battle. For the issue was the cavalry, difficult to control, devoid of extensive commanding structures ${ }^{11}$, where courage and bravery are of greater importance than order and absolute submission to superiors. Consequently, the Polish-Lithuanian cavalry is identified by certain researchers with the medieval style of combat, whereas infantry units ordered with mathematical precision, trained on drill manuals, make up a personification of modernity and military transformations. Peter Englund described it figuratively, defining the failed charge of the hussars in the battle of Warsaw (1656) as "the last eighty meters of Middle Ages"12. In particular the Polish historiographers claim that this and similar opinions have nothing to do with reality and point at the examples of successful cavalry attacks (especially the hussars) on infantry units ${ }^{13}$.

Resolving the dispute with the use of narrative history is actually futile. The supporters of both views are able to show enough examples to support their thesis, whereas the opposite situations are easily justified with subjective circumstances, which affected the final result of the clash. An attempt at a more objective settlement of the dispute is establishing the effectiveness of $17^{\text {th }}$-century musket fire and assessing the armor resistance

6 The main assumptions of the „Old-Polish art of war” was presented as early as the interwar period in the work: O. Laskowski, Odrębności staropolskiej sztuki wojennej, Przegląd Historyczno-Wojskowy, Vol. 6, No 1, 1935: 1-35 (in Polish). Certainly, the concept was adapted to the enemy's military forces and the terrain of the warfare. Wars were different in Livonia or Prussia, from those in the Ukraine.

7 W. Krawczuk, Wojna szarpana doby „potopu” - doświadczenia szwedzkie, Zeszyty Naukowe Uniwersytetu Jagiellońskiego. Prace Historyczne, Vol. 143, No 4, 2016: $737-742$ (in Polish); J. Wojtasik, Wojna szarpana Stefana Czarnieckiego w dobie potopu szwedzkiego (1655-1660), in Z dziejów stosunków Rzeczypospolitej Obojga Narodów ze Szwecją w XVII wieku, M. Nagielski (ed.), Wydawnictwo DiG, Warszawa, 2007: 183-200. K. Łopatecki, Pierwszy poetycki traktat wojskowy z mapą - Jana Kunowskiego Odsiecz smoleńska. Wykorzystanie kartografii w działaniach operacyjnych (1616-1617), Rocznik Lituanistyczny, Vol. 4, 2018: 41-75 (in Polish).

8 B. Bomanowski, Współdziałanie wojsk Rzeczypospolitej Obojga Narodów w pierwszym etapie walk kampanii cudnowskiej, Acta Universitatis Lodziensis. Folia Historica, Vol. 95, 2015: 65-87 (in Polish).

9 C.J. Rogers, Tactics and the face of battle, in European Warfare, 1350-1750, F. Tallett, D.J.B. Trim (ed.), Cambridge University Press, Cambridge, 2010: 203-235; F. Tallet, War and Society in Early-Modern Europe, 1495-1715, Taylor \& Francis, London-New York, 2003: 44-50.

10 M. Cibicki, Taktyka jazdy staropolskiej, Przegląd Kawaleryjski, Vol. 4, No 2, 1927: 212-222 (in Polish); P. Florek, Z taktyki wojsk polskich podczas działań wojennych w Moskwie 1608-1611, Czasy Nowożytne, Vol. 4, 1998: 167-187 (in Polish).

11 In the national contingent, a unit was commanded by a rotmistrz, who had his deputy, in case he was absent, a lieutenant (porucznik). In the face of progressing absence (in particular in the 18th century) of commanders, the lieutenant's representative was a namiestnik. Additionally, there was a chorąży and signalers being part of the rotmistrz's poczet. All remaining functions had to be performer by privileged soldiers called in the sources „towarzyszes”, who can be referred to as non-commissioned officers. Within their poczets they had „pocztowys” registered in the army personel. The pay of the pocztowys was directly handed to the towarzyszes; they did not participate in the soldiers' self-governing bodies, the so-called "military circles". J. Urwanowicz, Wojskowe „sejmiki”. Koła w wojsku Rzeczypospolitej XVI-XVIII wieku, Wydawnictwo Uniwersytetu w Białymstoku, Białystok, 1996 (in Polish); M. Plewczyński, Skład chorągwi jazdy koronnej w latach 1501-1572, Studia i Materiały do Historii Wojskowości, Vol. 35, 1993: 33-56 (in Polish); T. Ciesielski, Armia koronna w czasach Augusta III, Wydawnictwo DiG, Warszawa, 2009: 251-279 (in Polish).

12 P. Englund, Lata wojen, W. Łygaś (transl.), Finna Oficyna Wydawnicza, Gdańsk, 2003: 33-38 (in Polish); P. Englund, Die Verwüstung Deutschlands: eine Geschichte des Dreissigjährigen Krieges, Klett-Cotta, Stuttgart, 1998: $29-39$ (in German). 13 For example: A.A. Majewski, Szarża husarska pod Warszawą 29 lipca 1656 roku, Przegląd Historyczno-Wojskowy, Vol. 13, No 3, 2012: 167-174 (in Polish). 
to infantry's fire ${ }^{14}$. The complexity of the phenomenon ${ }^{15}$, as well as insufficient empirical studies, do not let us clearly assess the situation ${ }^{16}$. On the contrary, they are more or less instrumentally used in the dispute in progress, by some as the evidence of a powerful breaking force, and by others as something the opposite ${ }^{17}$.

However, the very diverse results of battles with the Polish-Lithuanian cavalry and the infantry arranged according to the West European type, indicates a relative balance of powers, where commanders-in-chief were able to use the enemy's weakness or to maximize their own advantage. On the battlefields, however, the key role was played by the troops' morale ${ }^{18}$. The battle was won, not by the one who managed to kill a greater number of enemies, but the one who first forced the enemy to flee ${ }^{19}$. A single deserter would trigger the fleeing of the whole unit, and after that subsequent units would follow suite which resulted in disaster ${ }^{20}$.

Hence, military theoreticians emphasized the necessity of applying any means to force the troops to fight (e.g. demolishing bridges, which cut off the escape route). They suggested serving alcohol before the battle, prayers/services were performed, speeches were delivered, friendship ties between the soldiers were propagated $^{21}$. Of crucial importance was, which is obvious, training and the skill of introducing and maintaining appropriate military discipline. Historiography adopted the term "revolution in drill", used for the first time by Michael Roberts ${ }^{22}$. It involved introducing absolute obedience, self-control of the soldiers, developing automatic reactions and training the skills for performing maneuvers by big groups of soldiers. The culmination of the transformations was to be "mass subordination", when the army was entirely subject to the will of the commander, like in the troops of ancient Rome. Regulations and manuals, which

14 R. Sikora, Fenomen husarii, Dom Wydawniczy DUET, Toruń, 2003: 12-45 (in Polish).

15 The studies conducted on the proces of superseding bows by firearms show that technological factors did not play the only, or even the most important role. In the proces the cultural, economic, social and political contexts were of importance. In England the change occurred as a result of the proces of enclosing, more and more difficult access to yew to construct bows from, and as a result of the conflict with Scotland. A similar situation referred to Russia, the Polish Crown and the Grand Duchy of Lithuania in reference to cavalry, where the bow was willingly used in the $16^{\text {th }}$ and $17^{\text {th }}$ centuries. P. Gervase, Longbow and Hackbutt: Weapons Technology and Technology Transfer in Early Modern England, Technology and Culture, Vol. 40, No 3, 1999: 576-593; A. Bołdyrew, The Bow in the Borderland in the 16th Century, Fasciculi Archeologiae Historicae, Vol. 30, 2017: 1117; D. Ostrowski, The Replacement of the Composite Reflex Bow by Firearms in the Muscovite Cavalry, Kritika: Explorations in Russian and Eurasian History, Vol. 11, No 3, 2010: 513-534.

16 Still, the most important studies on the effectiveness of the 17th-century firearms were conducted in the years 1988-1989 in Landeszeughaus in Graz (Austria), where the items residing there were tested. Those and other empirical studies should be perceived very cautiously, which is discussed by: Recently, a comprehensive study on the effectiveness of distance weapons: P. Krenn, P. Kalaus, B. Hall, Material Culture and Military History: Test-Firing Early Modern Small Arms, Material History Review, Vol. 42, 1995: 101-109. Na te i inne empiryczne badania należy spojrzeć z dużą ostrożnością o czym pisze: W.F. Refshauge, A note on physical properties of musket fire, Journal of Conflict Archaeology, Vol. 10, No 3, 2015: 149-153. Ostatnio syntetyczne studium o skuteczności broni dystansowej: A. Kott, P. Perconti, N. Leslie, Discovering a Regularity: the Case of An 800-year Law of Advances in Small-Arms Technologies, https://arxiv.org/pdf/1908.03435 (access: 8.01.2020).

17 Importantly, reenactment groups are more interested in the issue than military historians, who prefer to use the information collected in archive queries, than the data resulting from experimental archeology.

18 From the perspective of the Crown troops, in the 16th century, this assumption is emphasized by A. Bołdyrew, Piechota zaciężna w Polsce w pierwszej połowie XVI wieku, Wydawnictwo Neriton, Warszawa, 2011: 341 (in Polish), who also accentuates that the rearmament of infantry rotas with firearms considerably reduced their effectiveness, whereas the psychological effect was inversely proportional to the efficiency of shots”. Compare: S. McLachlan, Medieval Handgonnes: The first black powder infantry weapons, Bloomsbury Publishing, Oxford, 2010.

19 It is estimated that in the 17th century in Europe, the winner lost in the battle c. 15\% of soldiers, while the loser twice as many (as well as lost c. 20\% of the army personnel as prisoners). The losses constituted $10-25 \%$ of the overall loss in the number of the troops. The rest was connected with diseases, wounds and desertion. Jointly, c. 2-14\% of the personnel was lost every month. F. Tallet, War and Society in Early-Modern Europe, 1495-1715, Taylor \& Francis, London-New York, 2003: 106; I. Gentles, The English Revolution and the Wars in the Three Kingdoms, 1638-1652, Pearson Education Limited, Harlow, 2007: 434.

20 As W. Kochowski claims, a shortcoming of the national contingent troops is the fact that "they attack the fleeing to the last, when they are winning, and rush into an unstoppable escape if the enemy is prevailing”. A. Kochowski, Lata potopu 1655-1657, A. Kersten (ed.), L. Kukulski (transl.), Ministerstwa Obrony Narodowej, Warszawa, 1966: 216 (in Polish).

21 F. Tallet, War and Society in Early-Modern Europe, 1495-1715, Taylor \& Francis, London-New York, 2003: 48-49.

22 M. Roberts, The Military Revolution, 1560-1660, in The Military Revolution Debate: Readings on the Military Transformation on Early Modern Europe, C. J. Rogers (ed.), Westview Press, Boulder 1995: 15; J.A. Lynn, Giant of the Grand Siècle. The French army, 1610-1715, Cambridge University Press, Cambridge, 1997: 513-546. 
can be referred to as "infantry art of war" served this purpose. A breakthrough was popularizing the Dutch reforms of the late $16^{\text {th }}$ century ${ }^{23}$, through a new form of communication. It consisted of a combination of visual techniques (illustrations) with descriptions involving practical aspects of unit functioning (drill), as well as performing actions by particular soldiers (commands). A breakthrough came in the year 1607, when "Wapenhandelinghe" was published, where soldiers' stances were presented graphically (made by Jacob de Gheyn) for commands prepared by Maurice of Orange ${ }^{24}$. The work was immediately translated from Dutch into English, German, Danish and French ${ }^{25}$. Thus, already in the second half of the first decade of the $17^{\text {th }}$ century, its content could be known to officers serving in all European armies. The new model was based on precepts, which replaced bans defined in articles of war. Additionally, the rules of obedience were executed by the supervision of the already extensive officer system ${ }^{26}$.

In the Commonwealth of the nobles, the first military regulations, actually referring to infantry, appeared in the second half of the $17^{\text {th }}$ century, but it was not until the next century that they started to play an important role ${ }^{27}$. Throughout nearly the whole early modern period articles of war and institutions guaranteeing execution of the introduced legal norms were of key importance ${ }^{28}$. The Polish and Lithuanian military laws dedicated a great deal of attention to the behavior of soldiers during a battle. Among them, the most important regulation was to stop the riders from a chaotic escape. The panic of a single rider transferred onto the whole unit, resulting in stampede and disorganization. Thus, all attempts of escape from the battlefield, which could be finished with a defeat of the whole army had to be blocked.

The solutions were seemingly simple: it was enough to adopt the regulations of the army of ancient Rome. With regard to deserting a battlefield, we know an appropriate regulation from the Digest, in the version edited by Modestinus (1) and Arrius Menander (2) ${ }^{29}$.

1) „Is, qui exploratione emanet hostibus insistentibus aut qui a fossato recedit, capite puniendus est”30.

2) „Qui in acie prior fugam fecit spectantibus militibus propter exemplum capite puniendus est”31.

23 T. Schwager, Militärtheorie im Späthumanismus: Kulturtransfer taktischer und strategischer Theorien in den Niederlanden und Frankreich (1590-1660), De Gruyter, Berlin, 2012: 192-261 (in German).

24 J. de Gheyn, Wapenhandelinghe von roers, musquetten ende spiessen ..., 's-Gravenhage, 1607 (in Dutch); S.J. Walker, Arms and the Man: Constructing the Soldier in Jacques de Gheyn's „Wapenhandelinghe”, Netherlands Yearbook for History of Art., Vol. 58, 2007-2008: 138-161.

25 K. Hoogendoorn, Bibliography of the Exact Sciences in the Low Countries from ca. 1470 to the Golden Age (1700), Brill, Leiden-Boston 2018: 376-382; G. Parker, Od domu orańskiego do domu Bushów: czterysta lat „rewolucji militarnej”, Przegląd Historyczny, Vol. 96, No 2, 1996: 233 (in Polish).

26 The contemporary tried to set the chaos of war in order, ascribing it the beauty of mathematical harmony, which in the social sphere was based on "order" (extremely frequently the word "Ordnung" was used in the states of the Reich). This shows that the treaties and then military regulations performer tasks of „social disciplining” (so-called Sozialdisziplinierung). Consequently, $16^{\text {th }}$-century treaties considered as the most important quality of the soldier obedience, understood as fulfilling the superior's orders, but also restraint in action and self-control. S.J. Walker, Arms and the Man: Constructing the Soldier in Jacques de Gheyn’s „Wapenhandelinghe”, Netherlands Yearbook for History of Art., Vol. 58, 2007-2008: 140-142; P. Szadkowski, Staropolskie i hiszpańskie piśmiennictwo wojskowe XVI wieku w kontekście teorii rewolucji militarnej. Próba porównania, Kwartalnik Historyczny, Vol. 125, No 3, 2018: 604-605, 611-614, 620-623; T. Schwager, Militärtheorie im Späthumanismus: Kulturtransfer taktischer und strategischer Theorien in den Niederlanden und Frankreich (1590-1660), De Gruyter, Berlin, 2012: 4+ (in German).

27 T. Ciesielski, Samuel Brodowski - kodyfikator prawa wojskowego w czasach panowania Augusta III, in Historia testis temporum, lux veritatis vita memoriae, nuntia vetustatis. Księga Jubileuszowa dedykowana Profesorowi Włodzimierzowi Kaczorowskiemu, E. Kozerska, M. Maciejewski, P. Stec (ed.), Wydawnictwo Uniwersytetu Opolskiego, Opole, 2015: $399-420$ (in Polish); J. Wimmer, Błażeja Lipowskiego pierwszy polski regulamin piechoty, Studia i Materiały do Historii Wojskowości, Vol. 20: 1976: 335-357 (in Polish).

28 K. Łopatecki, „Disciplina militaris” w wojskach Rzeczypospolitej do połowy XVII wieku, Instytut Badań nad Dziedzictwem Kulturowym Rzeczypospolitej, Białystok, 2012 (in Polish).

29 W. Ashburner, The Byzantine Mutiny Act, The Journal of Hellenic Studies, Vol. 46, 1926: 80-81, 89-90. See J. H. Jung, Die Rechtsstellung der römischen Soldaten. Ihre Entwicklung von den Anfängen Roms bis auf Diokletian, in Aufstieg und Niedergang der römischen Welt, Bd. II/14, H. Temporini (ed.), Berlin, 1982: 882-1013 (in German).

30 Modestinus in Digesta 49. 16. 3. 4 (in Latin).

31 Arrius Menander in Digesta 49. 16. 6. 3 (in Latin). See C. E. Brand, Roman Military Law, University of Texas Press, AustinLondon, 1968: 184. 
In particular, Menander's second norm leaves no doubts: the first who escaped from the battlefield should be condemned to death ${ }^{32}$. Literature of the subject points out that it was a milder norm than decimation, which affected the whole unit ${ }^{33}$. In reality, they were two mutually complementary forms of an offence, which involved escaping a battlefield. They differed from the classic form of desertion (which is characterized by the intention of permanently leaving the army), as well as insubordination (or conscious disobedience to a superior's will). In the case under analysis, the soldier takes actions in accordance with the order and performs them until his will is broken by fear and self-preservation instinct. The law regulated the case of the first to begin escaping, thus that mentally least resistant. Thereby the norm was introduced in order to set a deterring example and force the other soldiers to keep their positions ${ }^{34}$. In the case of escape of the first, it was important to stop the whole unit in the position; hence the penalty of decimation (killing every tenth soldier).

The Roman law provided a guideline for European legislators of the modern period on how to strengthen formation during a battle. In the Polish and Lithuanian army, ancient solutions were adopted but also adjusted to the specificity of the units. Of key importance was the powers of all soldiers to administer justice to "cowards". Consequently, the articles of war allowed participants of battles to wound or even kill fugitives during the battle ${ }^{35}$.

In the Crown, we should recognize Jan Tarnowski as the author of the solution, who adopted the norm from imperial regulations ${ }^{36}$. From c. mid-16 ${ }^{\text {th }}$ century, the following regulation was incessantly binding: "Everyone can kill the one who escapes from the battle, and if he does escape anyway he is infamous" ${ }^{37}$ Soldiers were also authorized to attack any type of defeatists, who suggested fleeing verbally ${ }^{38}$. In the Grand Duchy of Lithuania norms authorizing to kill fugitives by soldiers were single and usually were not adopted. Regulations modelled on those in the Crown were introduced only in 1635 by Krzysztof Radziwiłt ${ }^{39}$. The solution was accepted by subsequent Lithuanian commanders-in-chief, until the first half of the $18^{\text {th }}$ century $^{40}$. The solutions binding in Lithuania entitled soldiers to kill the fugitive, not only during the battle, but at any later moment. The fugitive was subject to civil death and could be legally killed at any moment.

32 This norm was referred to by the supreme Polish military auditor: S. Brodowski, Corpus iuris militaris Polonicum, Drukarnia Nieboszczyka Preussa, Elbląg, 1753: 408 (in German and Polish).

33 Ł. Różycki, Mauricii Strategicon. Praktyczny podręcznik wojskowy i dzieło antykwaryczne, Instytut Historii UAM, Poznań, 2015: 141-142 (in Polish); J. Den Boeft, J.W. Drijvers, D. Den Hengst, H.C. Teitler, Philological and Historical Commentary on Ammianus Marcellinus: XXIV, Brill, Liden-Boston-Köln, 2002: 74-75.

34 G. Kuleczka, Studia nad rzymskim wojskowym prawem karnym, Uniwersytet im. Adama Mickiewicza, Poznań, 1974: 93-94 (in Polish); V. Péter, De re militari (A katonai jogról - forráselemzés), in Acta Universitatis Szegediensis: acta juridica et politica, Vol. 57, No 11, 1999 (in Hungary): 11; M.V. Girvés, Violación del Sacramentum y Crimen maiestatis: la cobardía en el ejército de Roma, Habis, Vol. 28, 1997: 172-173 (in Spain).

35 My detailed analysis of several dozen Polish and Lithuanian normative acts can be found in: K. Łopatecki, Przestępstwo ucieczki z pola bitwy w Rzeczypospolitej szlacheckiej - z badań nad karą śmierci wymierzaną w trybie pozasądowym, in Culpa et poena. Z dziejów prawa karnego, M. Mikuła (ed.), Wydawnictwo Uniwersytetu Jagiellońskiego, Kraków, 2009: 189203 (in Polish).

36 K. Łopatecki, „Disciplina militaris” w wojskach Rzeczypospolitej do połowy XVII wieku, Instytut Badań nad Dziedzictwem Kulturowym Rzeczypospolitej, Białystok, 2012: 155-156 (in Polish).

37 Instrukcje i artykuły hetmańskie Jana Tarnowskiego, Z. Spieralski (ed.), Studia i Materiały do Historii Wojskowości, Vol. 36, 1994: 302 (Art. 29) (in Polish); Polskie ustawy i artykuły wojskowe od XV do XVIII wieku, S. Kutrzeba (ed.), Polska Akademia Umiejętności, Kraków, 1937: 68 (Art. 29), 114 (Art. 26), 145 (Art. 18), 190 (Art. 35), 214 (Art. 1), 284 (Art. 4), 338 (Art. 28 ), 351 (Art. 70) (in Polish). See: G. Błaszczyk, Ustawy i artykuły wojskowe Polski i Litwy do 1569 roku, Studia i Materiały do Historii Wojskowości, Vol. 39, 1998: 50-51 (in Polish).

38 Polskie ustawy i artykuły wojskowe od XV do XVIII wieku, S. Kutrzeba (ed.), Polska Akademia Umiejętności, Kraków, 1937: 122 (Art. 9) (in Polish). So, for example, during the retreat of the camp from Cecora in 1620, when one of the soldiers spreading panic shouted „The hetmans are fleeing”, was killed with a saber by Stanisław Koniecpolski in order to show that it was a hoax. Pamiętniki o Koniecpolskich. Przyczynek do dziejów polskich XVII wieku, S. Przyłęcki (ed.), Nakładem Leona Rzewuskiego, Lwów, 1842: 169 (in Polish).

39 Archival Material, Archiwum Główne Akt Dawnych, Archiwum Radziwiłłów II, 1154: 10 (Art. 54); Polskie ustawy i artykuły wojskowe od XV do XVIII wieku, S. Kutrzeba (ed.), Polska Akademia Umiejętności, Kraków, 1937: 245 (Art. 54) (in Polish).

40 Polskie ustawy i artykuły wojskowe od XV do XVIII wieku, S. Kutrzeba (ed.), Polska Akademia Umiejętności, Kraków, 1937: 257 (Art. 42), 268 (Art. 59); Archival Material, Archiwum Główne Akt Dawnych, Archiwum Radziwiłłów VII, 5: 43 (Art. 19 ). 
In the Crown in the mid-17 $7^{\text {th }}$ century there emerged postulates de lege ferenda proposing extending the application of the punishment according to the Lithuanian model. It was problematic to legally assess the "infamous" person [rogue/rascal: K.є] ${ }^{41}$. The military theoretician Szymon Starowolski underscored the necessity of cultivating social infamy against fugitives from the battlefield. He referred to examples from Polish history, as well as solutions existent in Antiquity. Beside the rules of ancient Rome or Sparta, he also mentioned the Macedonians. The latter allegedly did not allow the fugitives to walk with their face uncovered, "but always with a wicker basket on the head, with which he would cover his eyes, and look at people through the rods. And if he uncovers himself, whoever sees him should punch him in his face" ${ }^{42}$. Andrzej Maksymilian Fredro, another $17^{\text {th }}$-century military theoretician proposed similar reform ${ }^{43}$.

Similar regulations were binding in the Polish-Lithuanian units of foreign contingent, or formations made based on the West European model ${ }^{44}$. It was allowed to would or even kill every fugitive without any legal consequence, and the first fugitive was subject to the punishment of "civil death": everyone could kill him without legal proceedings; from that moment on he was treated as infamous ${ }^{45}$.

Certain changes began to occur in the $18^{\text {th }}$ century. The first sign was articles of war binding in the foreign contingent and modelled on Saxon regulations. August II recognized escape as a form of desertion, which should be punished in accordance with general judicial rules ${ }^{46}$. However, it was an exception and only the articles written in the second half of the $18^{\text {th }}$ century replaced the extrajudicial death penalty with an ordinary procedure ${ }^{47}$. The right of privates to kill even officers was restored in certain situations in the revolutionary period of the Kościuszko Insurrection (1794). However, it was clarified that one may shoot the officer if he walks 30 steps away from his position ${ }^{48}$.

The changes resulted in part from Enlightenment ideas, which reached the Commonwealth ${ }^{49}$. No less important was an attempt to revalue the hierarchy of soldier's values. Obedience and social order were already a more important quality than their courage (and its antithesis, cowardice). The analysed regulation infringed on the order of commanding structures, provided a soldier with a powerful instrument, which could be applied also against a superior, and which could result in mutual distrust and chaos. Jan Michał Kampenhausen, the most important military theoretician of the Saxon period, depicted the problem. He advised officers not to apply corporal punishments and not to offend their inferiors before a battle, because during combat they may want to take revenge ${ }^{50}$. Jan Kiliński, participant in the Kościuszko Insurrection (1794) presented a description

41 If there emerged a suspicion that a person escaped from the battlefield, the person should be exonerated. Such a situation happened to a castellan, unknown by name. After the defeat of the Crown army at Pidhaitsi, he requested Jan Jabłonowski to put a word for him to the king. Significantly, the diarist did not give the person's data trying to protect the family from the loss of good name. J.S. Jabłonowski, Pamiętniki, A. Bielowski (ed.), Zakład Narodowy im. Ossolińskich, Lwów, $1862: 62$ (in Polish). 42 S. Starowolski, Prawy rycerz, K. J. Turowski (ed.), Wydawnictwo Biblioteki Polskiej, Kraków, 1858: 14-15 (in Polish).

43 J.M. Fredro, O porządku wojennym i o pospolitem ruszeniu, K. Pollak (ed.), Wydawnictwo Biblioteki Polskiej, Sanok, 1856: 34-36 (in Polish).

44 The laws binding in those units were based on Swedish solutions: K. Łopatecki, Artykuły wojskowe autoramentu cudzoziemskiego Władysława IV - okoliczności powstania i ich charakterystyka, Zeszyty Prawnicze UKSW, Vol. 11, No 2, 2011: 235-255 (in Polish).

45 Archival Material, Rossijskaâ Nacional'naâ Biblioteka (Sankt Petersburg), Otdel rukopisej, Avtografi Dubravskago (Fond 971), 321/2, No 243 (art. 29, 32, k. 3v), 244 (art. 20, k. 13); Polskie ustawy i artykuły wojskowe od XV do XVIII wieku, S. Kutrzeba (ed.), Polska Akademia Umiejętności, Kraków, 1937: 214 (Art. 1) (in Polish).

46 Polskie ustawy i artykuły wojskowe od XV do XVIII wieku, S. Kutrzeba (ed.), Polska Akademia Umiejętności, Kraków, 1937: 294 (Art. VIII) (in Polish); S. Brodowski, Corpus iuris militaris Polonicum, Drukarnia Nieboszczyka Preussa, Elbląg, 1753: 144-146 (in German and Polish).

47 Archival Material, Archiwum Główne Akt Dawnych, Archiwum Radziwiłłów VII, 260: 30 (Art. 18), 62 (Art. 18); Konfederacja Barska. Wybór tekstów, W. Konopczyński (ed.), Krakowska Spółka Wydawnicza, Kraków, 1928: 110-111 (Art. 4, 12) (in Polish); W. Organiściak, Kodeksy wojskowe w Polsce roku 1775, Wydawnictwo Uniwersytetu Śląskiego, $2001: 81$ (in Polish).

48 J. Kiliński, Pamiętniki, S. Herbst (ed.), Państwowy Instytut Wydawniczy, Warszawa, 1958: 152 (in Polish).

49 Archival Material, Archiwum Narodowe w Krakowie, Archiwum Podhoreckie II, 171: 262-263; W. Organiściak, Ze studiów nad reformą prawa wojskowego za czasów Stanisława Augusta, Czasopismo Prawno-Historyczne, Vol. 53, No 1, 2001 : 189 (in Polish); W. Organiściak, Kara śmierci w prawie wojskowym Rzeczypospolitej szlacheckiej od XVI do XVIII wieku, Problemy Prawa Karnego, Vol. 20, 1994: 84 (in Polish); W. Organiściak, Wpływ idei humanitarnych na kodyfikację prawa wojskowego Rzeczypospolitej w 1775 roku, Problemy Prawa Karnego, Vol. 22, 1997: 126-127 (in Polish).

50 Archival Material, Biblioteka PAN w Kórniku, 659: 244. 
of such a phenomenon. One of the soldiers killed an officer explaining that the latter was fleeing. At first, the private was not believed; he was accused of murder and sentenced to death. Finally, the sentence was not executed but the whole unit was lectured that obedience is sacred ${ }^{51}$. An attempt to reconcile the old and new tendencies was presented by an experienced jurist of military law of the mid-18 ${ }^{\text {th }}$ century, Samuel Brodowski. He authorized only officers and non-commissioned officers to kill fleeing soldiers ${ }^{52}$.

How should we classify the legal regulations referring to the situation connected with escape during a battle? To answer this question, we should point at its characteristic qualities. First, the soldier had a right, not an obligation, to kill or to wound the fugitive ${ }^{53}$. Second, the crime of escape from the battlefield was determined by the very fact thereof and its assessment by the comrades-in-arms. Neither a judicial sentence nor a commander's decision was necessary. Third, killing a soldier leaving the formation was connected with not only lack of penal liability but also with an award. In this context, the institution appears as a facultative passing administering justice by the state to soldiers in general. The act of killing a fugitive is not only unpunished (as in the case of a countertype, or the circumstance excluding the penal illegality of the act), but also devoid of the illegality in question.

In my opinion, the institution constituted a testimony of the rules of "free soldiers". In the West of Europe the landsknechts could be considered as this group, and in the Commonwealth their ideological equivalent was the national contingent $t^{54}$. As Olaf van Nimwegen presents, the subsequent period of early modern armed forces was the time of disciplined "mercenaries", who transformed into a permanent army of professional soldiers ${ }^{55}$. The powers to punish comrades were connected with the primary judicial and self-governing privilege of the soldiers.

To illustrate the phenomenon it is worth showing regulations applicable for mercenary armies in Europe. A perfect example is Sweden's army, which in the $16^{\text {th }}$ century was considerably based on recruiting landsknechts. For this reason the oldest Swedish articles of war were issued in 1535. Gustav I Adolph introduced a regulation similar to that of the Polish Crown (of course, they both were of ancient origins, adopted through the German military law). Article 34 informed the soldiers that anybody escaping during the battle or attack, may be killed by their comrades. In the case of escape, such a person was recognized till the end of his life as a villain. Characteristically, the regulation was addressed to infantry, because the execution of justice was to be with pikes or swords ${ }^{56}$. Subsequent normative acts consistently applied the rules developed at the beginning of the existence of the kingdom. For example, on June 12, 1592, Duke Charles of Södermanland (later Charles IX of Sweden), on behalf of the king of Sweden and the Commonwealth (Sigmund III Vasa) issued articles of war for German mercenaries. They repeated the previous rules, and additionally guaranteed to the executor the provision that for killing a comrade he would receive praise and thanks ${ }^{57}$. The solution was adopted

51 J. Kiliński, Pamiętniki, S. Herbst (ed.), Państwowy Instytut Wydawniczy, Warszawa, 1958: 134-137 (in Polish).

52 S. Brodowski, Corpus iuris militaris Polonicum, Drukarnia Nieboszczyka Preussa, Elbląg, 1753: 408 (in German and Polish). 53 The contemporary believed that certain deeds judged a man themselves (,ipso facto”); and therefore no judicial administration of justice was not necessary. J. Kamiński, Historia sądownictwa wojskowego w dawnej Polsce, Towarzystwa Wiedzy Wojskowej, Warszawa, 1928: 40-42, 53 (in Polish).

54 Certainly, I do not suggest identifying the formations, which mutually considerably differred in terms of organization. See: K. Koranyi, Żołnierz najemny, a żołnierz zaciężny, Czasopismo Prawno-Historyczne, Vol. 1, 1948: 105-108 (in Polish). I only point at a certain similarity connected with the empowerment of the soldiers, who had their own self-governing bodies („military circles”); they had the right to elect certain officers, participate in decision making and judiciary. E. Swart, From „Landsknecht” to Soldier: The Low German Foot Soldiers of the Low Countries in the Second Half of the Sixteenth Century, International Review of Social History, Vol. 51, No 1, 2006: 79-80, 82-83; J. Urwanowicz, Wojsko Rzeczypospolitej wobec polityki (na tle postaw armii europejskich), in Dziedzictwo pierwszej Rzeczypospolitej w doświadczeniu politycznym Polski i Europy, J. Ekes (ed.), Wydział Studiów Politycznych WSB-NLU w Nowym Sączu, Nowy Sącz, 2005: 25-38 (in Polish).

55 O. v. Nimwegen, The Transformation of Army Organization in Early-Modern Western Europe, c. 1500-1789, in European Warfare, 1350-1750, F. Tallet (ed.), Cambridge University Press, Cambridge, 2001: 159-180.

56 Des gemainen furs kriegsvolg gethane aidtsvorpghlichtunge actum wie volget, Uppsala 10 I 1535, Riksarkivet, Militaria, 903 : [16] (Art. 34) (in German).

57 Whereas the fugitives who survived were to be deprived of fame, and possibly having been caught, they should be killed. Karl IX krigsariklar, Sztokholm 12 VI 1592, Riksarkivet, Militaria, M 904, briefcase 2: [5] (Art. 10-11) (in German). 
in the best-known Swedish articles of war, those of Gustav II Adolph in 1621. They contained two norms regulating the issue. One concerned fleeing from under the standard; in this situation comrades were authorized to kill the deserters. The other case referred to the first fugitive from the battlefield. He could be killed both while fleeing, as well as any time after that, since he would be considered a traitor (thus, as a dead person: the so-called civil death) ${ }^{58}$. After that period the powers of soldiers began to be restricted in Sweden. The revision of the articles issued during fights in the Reich in the years 16321633 military judicial system was strengthened. The rule was clearly emphasized throughout chapter IX referring to escape from the battlefield. In one case only it provided for a possibility of wounding or killing a fugitive, but those powers were presented as supplementary to the general principle of judicial capital punishment for this crime ${ }^{59}$. Moreover, in Charles XI's articles of 1683, the right to execute justice during a battle was revoked completely (art. 62-70). In all cases they introduced a courtmartial against deserters fleeing from the battlefield, fortifications or leaving their standards ${ }^{60}$. Along with soldiers passing from the structures of free soldiers to the standing army of professional soldiers, the old rules applicable in battlefields were (even though delayed) revoked.

The regulation had its genesis and also lasted very long in the states of the Reich with its strong tradition of the use of landsknechts' services. The example of the Swedish laws of 1535 and 1592 was absolutely typical of this geographical area ${ }^{61}$. Of key importance were the articles of war announced to the landsknechts in 1508 by Maximilian I Habsburg62. Of no less importance were the Austrian regulations of 1527 issued by Ferdinand I Habsburg, which imposed the title of villain (rogue), which meant a legal death of the person ${ }^{63}$. The Spanish army knew similar solutions, which underscored the necessity of punishing with death "from the hand of any officer or solder" also people verbally arising panic or defeatism. The one who dealt "the blow of justice" was to receive an award for his stance ${ }^{64}$.

Analogous legal norms occurred at the turn of the $17^{\text {th }}$ century. The solution was provided for in, for example, the articles of war issued for the needs of Wurttemberg troops in 1588, and Bavarian troops in $1601^{65}$. Similar solutions also existed in the Brandenburg-Prussian articles of war of $1656^{66}$. However, transformations occurred even in that geographical area, and consequently a revaluation of

58 Code of articles of king Gustavus Adolphus of Sweden (1621), in W. Winthrop, Military Law and Precedents, Government Printing Office, Washington, 1920: 910 (Art. 56, 61). The original Swedish edition (of 150 articles): Krijgz articlar, som fordom then stormechtigste furste och herre, herr Gustaff Adolph, then andre och store Sweriges, Goethes och Wendes, Konung storfurste til Finland, Stockholm, 1621: [15] (Art. 59) (in Sweden).

59 Schwedisches Kriegs-Recht oder Articuls-Brieff desz ... Herrns Gustaff Adolffs ..., Heylbrunn, 1632: 17-18 (titulus IX, Art. 47-52), (in German).

60 Königs Caroli XI in Szweden Kriegs-Recht und Articulus-Brieff, in Corpus iuris militaris des heiligen Römischen Reichs, J. C. Lüning (ed.), Leipzig, 1723: 1343-1345 (titulus IX, Art. 62-70) (in German).

61 For example: the Prussian articles of war for infantry before 1555. Die Kriegsordnung des Markgrafen zu Brandenburg Ansbach und Herzogs zu Preussen Albrecht des Älteren: Königsberg 1555, H.J. Bömelburg, B. Chiari, M. Thomae (ed.), Archiv Verlag, Braunschweig, 2006: 228 (in Polish).

62 Kaysers Maximiliani I Articuls-Brieff, de Anno 1508, in Corpus iuris militaris des heiligen Römischen Reichs, J. C. Lüning (ed.), Leipzig, 1723: 3-4 (in German). Article 23 read: „Im Fall, da auch jemand Anlauff und Bestürmung der Mauren, oder auch in der Schlacht und mit denen Feinden zu haltenden Treffen zurückweichen, oder sich auf die flucht wenden oder begeben würde wollen, einen solchen soll ein jedweder, der zunächst an und neben ihm stehet, nach Krafft des geleisteten Eydes, durchstrossen und ums Leben bringen”. The importance of those articles of war was great, since nearly all sets of military laws began with or included in their content this act of law.

63 Kriegsartikel König Ferdinands I. vom Jahre 1527, in H. Meynert, Geschichte der k. k. österreichischen Armee, ihrer Heranbildung und Organisation, Bd. II, C. Gerold \& sohn, Wien, 1852: 57 [Art. 21] (in German).

64 S. de Londoño, Rozważania o sposobie przywrócenia dyscypliny wojskowej do jej klasycznej i doskonalszej postaci, P. Szadkowski (transl. and ed.), Napoleon V, Oświęcim, 2016: 92 (in Polish).

65 Artikel: Brief für das Fußvolk, vom 11. Januar 1588, in Sammlung der württembergischen Gesetze: Kriegs-Gesetze, Theil 1: Enthaltend die Kriegs-Gesetze von 1360 bis 1800, S.F.J. von Kapff (ed.), Tübingen, 1849: 85 [art. 11] (in German); Artikelsbrief Herzog Maximilians I, auf die Knechte von 1601, in E. von Frauenholz, Das Heerwesen in der Zeit des Dreissigjährigen Krieges, Vol. 3, No 1: Das Söldnertum, C.H. Beck’sche Verlagsbuchhandlung, München, 1938: 201-213.

66 Churfürstliches Brandenburgisches Kriegsrecht oder Articuls-Brieff Brandenburgisches Kriegsrecht oder Articuls-Brieff, in Corpus Constitutionum Marchicarum, Vol. 3: Von Kriegs-Sachen, betreffend den Militair-Process, Disciplin, Straffen..., Berlin-Halle, 1737: 59-69 (Art. 34, p. 63) (in German). 
the desired qualities. Thus, the articles of war binding in the County Palatine of the Rhine announced in 1674 by Charles Louis Wittelsbach envisaged for fugitives "only" a capital punishment applied in the judicial mode ${ }^{67}$.

Probably the place in Europe where those powers were revoked was the Dutch army, which at the beginning of the eighty-years' war soon imposed on landsknechts rules submitting them to strict discipline and control. The mercenaries were deprived of their previous powers from the beginning of the second half of the $16^{\text {th }}$ century, and the process intensified in the 1570 s and 80 s, which resulted in transforming the landsknechts into disciplined mercenary troops ${ }^{68}$. Significantly, the fundamental Dutch articles of war of 1590 had already removed the right of the soldiers to legally make their own judicial decisions during fights. Obedience to officers was more important than potential greater determination and courage of the soldiers during the clash. Any symptom of insubordination would be punished in judicial proceedings ${ }^{69}$.

It was similar in Russia, but the example is peculiar since the native regulations did not emerge until the end of the $17^{\text {th }}$ century ${ }^{70}$. In accordance with the Europe-wide trend, the articles of war of 1706 provided for judicial penalties only ${ }^{71}$. It was similar in the fundamental act of 1716 , where persons accused of this crime were to be deprived of fame (considered villains/rogues), and in the event of their catching, they should be "hanged on the first branch" without any trial. They also added the right of the officer to excuse a wounded soldier from the battlefield ${ }^{72}$.

English articles of war did not know examples of passing the power of administering justice during fights to all soldiers. Exceptionally, however, commanders decided to agree to such extraordinary situations. An example is the proclamation of General Robert Venables to the English troops fighting for conquering Spanish Jamaica in 1655. He ordered that the closest soldier killed the fugitive; otherwise he is subject to capital punishment himself. In this order the general broke a certain border, which was based on the law, and not on the obligation of other soldiers to exercise the articles of war ${ }^{73}$.

The Polish-Lithuanian legal tradition did not differ from other solutions of Central Europe. The powers granted to soldiers were of course applied exceptionally, but their potential could be important in the final assessment of the army's morale. Therefore, an additional group of people were introduced in the PolishLithuanian units, who were to have a special right of supervision over the soldiers' behavior during the battle. The source describes them as "supervising towarzyszes or "flank towarzyszes" 74 .

67 Articuls-Brieff Darnach Deß Durchleuchtigsten Fürsten und Herrn Herrn Carl Ludwigen Pfaltzgrafen, [Friederichsburg, 1674]: 8 (Art. 17).

68 See E. Swart, From „Landsknecht” to Soldier: The Low German Foot Soldiers of the Low Countries in the Second Half of the Sixteenth Century, International Review of Social History, Vol. 51, No 1, 2006: 75-92.

69 Lawes, Articles, and Ordinances touching marshall discipline, Arnhem 13 VIII 1590, in An Appendix Of the Lavves, Articles, \& Ordinances, established for Marshall Discipline..., Hagh, 1643: 1-7 (in particular p. 5, Art. 51, 54-55).

70 As early as 1699, Peter I vested preparing Polish articles of war in General Adam Weyde. The works were not completed and we know only a limited number of the crimes and the punishments for them. P.O. Bobrovskiy, Veyde Adam Adamovich. Odin iz glavnykh sotrudnikov Petra Velikogo i yego voyennyy ustav1698 goda. (Istoriko-yuridicheskoye issledovaniye), tip. Imp. un-ta, Kazan', 1887: 18-20 (in Russian).

71 Archival Material, Archiwum Główne Akt Dawnych, Archiwum Radziwiłłów, VII, 712: 60 (Art. VIII.6); Archival Material, Archiwum Narodowe w Krakowie, Archiwum Podhorodeckie II, 39: 1588 (Art. VIII.6).

72 Kodeks wojskowy Piotra I z 1716 roku, P. Krokosz, K. Łopatecki (ed.), Napoleon V, Kraków-Oświęcim, 2016: 198 (Art. 94 ) (in Polish). This codification was based, to a considerable degree, on the Swedish articles of war of 1683. E. Anners, Den karolinska militärstraffrätten och Peter den stores krigsartiklar, Almqvist \& Wiksell, Uppsala, 1961: 117-146 (in Sweden).

73 H. Marshall, Military Miscellany, comprehending a History of the Recruiting of the Army, Military Punishments, John Murray, Albemarle Street, London, 1846: 127.

74 J. Wojtasik J., Ordynacja hetmańska dotycząca taktyki wojsk polskich z początku XVIII w., Studia i Materiały do Historii Wojskowości, Vol. 6, No 1, 1960: 289-290 (in Polish); J. Teodorczyk, Bitwa pod Gniewem (22 IX - 29 IX - 1 X 1626). Pierwsza porażka husarii, Studia i Materiały do Historii Wojskowości”, Vol. 12, 1966: 165 (in Polish); M. Wagner, Podoficerowie armii koronnej w drugiej połowie XVII w., Studia i Materiały do Historii Wojskowości, Vol. 34, 1992: 70 (in Polish); K. Łopatecki, Przestępstwo ucieczki z pola bitwy w Rzeczypospolitej szlacheckiej - z badań nad karą śmierci wymierzaną w trybie pozasądowym, in Culpa et poena. Z dziejów prawa karnego, M. Mikuła (ed.), Wydawnictwo Uniwersytetu Jagiellońskiego, Kraków, 2009: 196-199 (in Polish). 
In order to explain their role, it is important first to characterize the formation of the cavalry in the early modern period. The articles of war published by Florian Zebrzydowski in 1561 inform about it ${ }^{75}$. In their light, the Polish cavalry set themselves in four lines. Towarzyszes and the best armed pocztowys should stand at the front. Well-armed pocztowys were placed in the rear line and on the sides. Finally, the smallest horses and the most weakly protected solders were to take place in the middle of the rota ${ }^{76}$. The places in the second line were to be taken by henchmen, who were obliged to provide assistance to the towarzyszes. Every pocztowy should, for example, give his own horse to the towarzysz if his master lost his horse. Of course, this system was not submissively copied; it was adapted to the needs. We have information from the years 1577-1580, that hussars were formed in five lines, and the elite best armed court units in merely three ${ }^{77}$. With the course of time they sought to reduce the number of lines (to two), to make the most of the impact force of the unit ${ }^{78}$. This formation had a few advantages. The first line was elite, so it was to have higher morale, necessary at the charge at the enemy, often protected by field fortifications firing with artillery and handguns. Additionally, the first line was occupied by the best armoured soldiers, on the best horses, due to which the unit was more resistant to fire.

However, there was a fundamental problem: cavalry units were nearly devoid of officers at the back and on the sides. At the front was the commander, a rotmistrz or a lieutenant, and issued or passed orders from the commander-in-chief. In the center was the standard held by a chorąży, which symbolized the honor of the unit and manifested the unit's readiness to fight ${ }^{79}$. However, officer ranks which would supervise the proper formation of the unit were missing. Although Florian Zebrzydowski constructed a four-line formation in order to locate the best of pocztowys at the rear, but in particular along with shallowing the lines the problem systematically increased ${ }^{80}$.

For this purpose they created a special, formally undistinguished, category of soldiers supervising the rear and the side of the unit. The supervising towarzyszes were expected to supervise the unit, encourage to fight, take care of forming the moving unit and appropriate squeezing the lines during the charge, counteract uncontrolled chases and chaotic escapes. Particular supervision was vested in them over pocztowys ${ }^{81}$. During the battle they could discipline unruly soldiers by force. "And if someone escaped the standard in the battle, a [towarzysz] supervising the lines should hack and slash him" ${ }^{82}$. This solution was to increase the determination of the unit so that "everyone preferred to fight the enemy in the battle to be surely killed by his own comrades from the back" ${ }^{83}$. It was an honourable function

75 Archival Material, Rossijskaâ Nacional'naâ Biblioteka (Sankt Petersburg), Otdel rukopisej, Avtografi Dubravskago (Fond 971), 321/1, No 1: 3.

76 In the light of the regulation of the beginning of the 18th century, the key factor was to be the officer's assessment referring to his subordinates' courage. The bravest should be in the first and the last line, the timid in the middle, and the cowards should be sent to the camp or other tasks. The commander's decision should not be known to everybody, because it seemed as if actually the weakest soldiers were awarded. Archival Material, Biblioteka PAU i PAN (Cracow), 974: 119v.

77 Diariusze relacje, listy i akta z lat 1576-1586, I. Polkowski (ed.), Polska Akademia Umiejętności, Kraków, 1887: 197,227 (in Polish); H. Kotarski, Wojsko polsko-litewskie podczas wojny inflanckiej 1576-1582. Sprawy organizacyjne, Vol. III, Studia i Materiały do Historii Wojskowości, Vol. 17, 1971: 116-117, (in Polish).

78 In the early 18th century, cavalry was to be formed into two lines, where the first line should contain towarzyszes and the best pocztowys. [H. Lubomirski], Ordynacja hetmańska, in J. Wojtasik, Ordynacja hetmańska dotycząca taktyki wojsk polskich z początku XVIII w., Studia i Materiały do Historii Wojskowości, Vol. 6, No 1, 1960: 291 (in Polish); E. Tyszkiewicz, Listy o Szwecji, Vol. II, Nakładem i drukiem Józefa Zawadzkiego, Wilno, 1846: 218-219 (in Polish).

79 To guard the standard (chorągiew), also one or two towarzyszes were appointed. See: Relacje wojenne z pierwszych lat walk polsko-kozackich powstania Bohdana Chmielnickiego okresu „Ogniem i Mieczem” (1648-1651), M. Nagielski (ed.), Viking Books, Warszawa, 1999: 322-323, 344 (in Polish).

80 Archival Material, Biblioteka PAU i PAN w Krakowie, 974: 119v.

81 J.M. Fredro, O porządku wojennym i o pospolitem ruszeniu, K. Pollak (ed.), Wydawnictwo Biblioteki Polskiej, Sanok, 1856: 35-36 (in Polish); Relacje wojenne z pierwszych lat walk polsko-kozackich powstania Bohdana Chmielnickiego okresu „Ogniem i Mieczem" (1648-1651), M. Nagielski (ed.), Viking Books, Warszawa, 1999: 343.

82 [H. Lubomirski], Ordynacja hetmańska, in J. Wojtasik, Ordynacja hetmańska dotycząca taktyki wojsk polskich z początku XVIII w., Studia i Materiały do Historii Wojskowości, Vol. 6, No 1, 1960: 291 (in Polish).

83 J.M. Fredro, O porządku wojennym i o pospolitem ruszeniu, K. Pollak (ed.), Wydawnictwo Biblioteki Polskiej, Sanok, 1856: 35-36 (in Polish); S. Łaski, Prace naukowe i dyplomatyczne, wyd. M. Malinowski, Nakładem i Drukiem Józefa Zawadzkiego, Wilno, 1864: 75 (in Polish). 
vested in first towarzyszes inspected in the rota ${ }^{84}$. They were exempted from burdensome administrativemilitary activities, for example, they were freed from the obligation of conducting wagons, allotting quarters, participating in raids, etc..$^{85}$

We can state that the supervising towarzyszes occurred nearly throughout the early modern period, at least in the period from the first half of the $16^{\text {th }}$ century until the first half of the $18^{\text {th }}$ century. Already in the oldest renaissance military treatise, probably written by Stanisław Easki in the 1540s, the author advised to establish such a formation. He suggested that at the back of all units and the whole army "good people" should be placed, who would treat fugitives like enemies ${ }^{86}$. It is not certain, if the author invented the institution or just wanted to popularize it. It is certain, however, that the establishment was fully adopted as early as the early 1560s. The propagator of this function was the commander of the Polish corps supporting the Grand Duchy of Lithuania in the fights for Livonia, Florian Zebrzydowski. According to him, there should be two supervising towarzyszes in each rota ${ }^{87}$. They should stand at the rear of unit and were entitled to catch or kill cowards ${ }^{88}$. In the $17^{\text {th }}$ century they were moved to the sides, may be in order to control more effectively the extended front (which lengthened along with the shallowing of the lines). Andrzej Maksymilian Fredro claimed that there should be four such towarzyszes in a rota, who should supervise the unit from the right and the left flank ${ }^{89}$. In practice, however, this responsibility was passed to one towarzysz and his poczet ${ }^{90}$. In 1704 a military regulation was issued, which provided for as many as six towarzyszes for a rota, which is two for the flanks and the additional two to supervise the rear of the unit ${ }^{91}$.

For the record, we should note the solutions binding in the foreign contingent. Modeled on the supervising towarzyszes behind the line of the troops, there were a few officers, who should kill the fleeing ${ }^{92}$. The impact of the national contingent was visible even in the articles of war of August III in 1750. The soldiers (not only officers) were authorized to shoot a gun at the first fugitive ${ }^{93}$. Apart from that group, there was also a reserve behind all the parties of the troops. It was led by officers who, on pain of severe punishment, were to stop the soldiers fleeing from the battlefield by all means. As the $18^{\text {th }}$-century military theoretician, Jan Michał Kampenhausen emphasized "they were allowed and sometimes ordered to open fire on them" ${ }^{94}$. This solution had a different philosophy behind it from that in the units of the national contingent and was connected with orders and not powers transferred to the soldiers.

The period of the Kościuszko Insurrection of 1794 is a short renaissance of the gradually abandoned tradition. It was adjusted to the new revolutionary time. It was not supervising towarzyszes but special groups that were to prevent desertion. Thus, before the battle of Krupczyce on September 17, 1794, Tadeusz Kościuszko ordered Karol Sierakowski, commander of a division, to detach a group of infantry with two

84 Relacje wojenne z pierwszych lat walk polsko-kozackich powstania Bohdana Chmielnickiego okresu „Ogniem i Mieczem” (1648-1651), M. Nagielski (ed.), Viking Books, Warszawa, 1999: 339 (in Polish); E. Tyszkiewicz, Listy o Szwecji, Vol. II, Nakładem i drukiem Józefa Zawadzkiego, Wilno, 1846: 218-219 (in Polish); M. Wagner, Podoficerowie armii koronnej w drugiej połowie XVII w., Studia i Materiały do Historii Wojskowości, Vol. 34, 1992: 69 (in Polish).

85 J.M. Fredro, O porządku wojennym i o pospolitem ruszeniu, K. Pollak (ed.), Wydawnictwo Biblioteki Polskiej, Sanok, 1856: 36 (in Polish).

86 S. Łaski, Prace naukowe i dyplomatyczne, wyd. M. Malinowski, Nakładem i Drukiem Józefa Zawadzkiego, Wilno, $1864: 75$ (in Polish).

87 Polskie ustawy i artykuły wojskowe od XV do XVIII wieku, S. Kutrzeba (ed.), Polska Akademia Umiejętności, Kraków, 1937: 99 (Art. 3.1).

88 Archival Material, Rossijskaâ Nacional'naâ Biblioteka (Sankt Petersburg), Otdel rukopisej, Avtografi Dubravskago (Fond 971), 321/1, No 1: 3v. (Art. [10]).

89 J.M. Fredro, O porządku wojennym i o pospolitem ruszeniu, K. Pollak (ed.), Wydawnictwo Biblioteki Polskiej, Sanok, 1856: 35 (in Polish).

90 Relacje wojenne z pierwszych lat walk polsko-kozackich powstania Bohdana Chmielnickiego okresu „Ogniem i Mieczem” (1648-1651), M. Nagielski (ed.), Viking Books, Warszawa, 1999: 339-343.

91 [H. Lubomirski], Ordynacja hetmańska, in J. Wojtasik, Ordynacja hetmańska dotycząca taktyki wojsk polskich z początku XVIII w., Studia i Materiały do Historii Wojskowości, Vol. 6, No 1, 1960: 291 (in Polish).

92 Archival Material, Biblioteka PAN w Kórniku, 659: 260v.

93 Archival Material, Archiwum Główne Akt Dawnych, Archiwum Radziwiłłów, VII, 5: 71 (Art. 18).

94 Archival Material, Biblioteka PAN w Kórniku, 659: 236v. 
cannons loaded with case shots before every action. That group was to station at the back and shoot at those fleeing from the field ${ }^{95}$. In addition, Kościuszko ordered so that every officer who would walk away 30 steps from the front line, could be shot at by any soldier ${ }^{96}$. Such solutions had serious consequences on the tactical level, about which Colonel Jan Kiliński wrote. Defending Warsaw from the Prussian forces, he observed the regrouping of the enemy's forces, which approached the capital. Thus, he decided to leave his unit to recognize if he should send support there. The lieutenant-colonel, however, reminded him Kościuszko's order referring to the possibility of shooting him because of leaving his position. This, however, did not stop Kiliński, even though the danger was real ${ }^{97}$.

Of course, the supervising towarzyszes not only prevent escapes ${ }^{98}$. The spectrum of their actions was much broader. We can reconstruct it on the basis of the most important early modern articles of war issued in $1609^{99}$. On the move, soldiers should not leave their unit without permission ${ }^{100}$. Before a battle, the soldiers were forbidden to lawlessly go skirmishing or to take part in duels, which were taking place between the frontlines of both armies. This was an activity very difficult to prohibit. The legislator explained, that it was certainly a very glorious and brave decision, but it may be dangerous for the whole army, which may be forced to take a battle in unfavourable conditions ${ }^{101}$. It was forbidden to take fights without the commanderin-chief's order, and also the reverse situation, when after the order to attack, the soldiers remained in their places $^{102}$. During the encounter itself the supervising towarzyszes were expected to prevent dispersion to search for jewellery or prisoners ${ }^{103}$. Moreover, it was prohibited to chaotically chase the fleeing enemy, of which was taken advantage by Tatar troops ${ }^{104}$. They pretended to flee in order to disperse their enemy's cavalry, where every knight chased an enemy on his own. Then the Tatar troops instantly formed up and destroyed the dispersed soldiers ${ }^{105}$. Additionally, they played an important role in the maneuvers of the unit, primarily while reversing ${ }^{106}$.

In summary, the Polish-Lithuanian cavalry units based their discipline during the battle on the articles, and not on military regulations. Thus, of key importance were prohibitions and not precepts

95 Rozkaz Najwyższego Naczelnika do dywizji generała - majora Karola Sierakowskiego, in J. Karwin, E. Pomianowski, S. Rutkowski, Z dziejów wychowania wojskowego w Polsce od początku państwa polskiego do 1939 roku, Wydawnictwo Ministerstwo Obrony Narodowej, Warszawa, 1969: 368 (in Polish).

96 J. Kiliński, Pamiętniki, S. Herbst ed., Państwowy Instytut Wydawniczy, Warszawa, 1958: 150 (in Polish).

97 Ibidem: 152 (in Polish).

98 The size of the unit should be adapted to the capabilities of the supervising towarzyszes; therefore, the optimum number of a rota should be 100-150 men. Larger units had to be divided so as to make it possible to control the soldiers' behavior. M. Nagielski, Chorągwie dworzańskie Jana Kazimierza podczas dwóch batalii kozackich 1649-1651, in Gospodarka, ludzie, władza: studia historyczne ofiarowane Juliuszowi Łukasiewiczowi w 75 rocznicę urodzin, M. Kopczyński (ed.), A. Mączak, Wydawnictwo Krupiński i S-ka, Warszawa, 1998: 117 (in Polish).

99 Polskie ustawy i artykuły wojskowe od XV do XVIII wieku, S. Kutrzeba (ed.), Polska Akademia Umiejętności, Kraków, 1937: 184 (Art. 4), 189 (Art. 31, 32) (in Polish).

100 J.M. Fredro, O porządku wojennym i o pospolitem ruszeniu, K. Pollak (ed.), Wydawnictwo Biblioteki Polskiej, Sanok, 1856: 36 (in Polish).

101 Quite a great deal of space was devoted to the issue in every military law, and in 1581 during the siege of Pskov a special rotmistrz circle was summoned, where they explained the absurdity of this action. Instead, they proposed a list to register the people who wanted to take part in the assault on the fortress. J. Piotrowski, Dziennik wyprawy Stefana Batorego pod Psków, A. Czuczyński (ed.), Nakładem Księgarni Spółki Wydawniczej Polskiej, Kraków, 1894: 67 (in Polish).

102 After all, situations where, against the orders of the commander, the Polis hor Lithuanian cavalry did not attack were not rare. This happened, for example, in 1633. Krzysztof Radziwiłł asked his soldiers to attack the Swedes ,and put his hands together beseeching [them] by living God, that they remembered their [high] birth and obligation”. Księcia Krzysztofa Radziwiłła sprawy wojenne i polityczne 1621-1622, Drukarnia L. Martinet, Paryż, 1859: 275-277.

103 K. Łopatecki, „Disciplina militaris” w wojskach Rzeczypospolitej do połowy XVII wieku, Instytut Badań nad Dziedzictwem Kulturowym Rzeczypospolitej, Białystok, 2012: 189 (in Polish).

104 B.L. Davies, Warfare, State and Society on the Black Sea Steppe, 1500-1700, Routledge, London - New York, 2007: 21-22; R. Majewski, Z problematyki walk z Tatarami w pierwszej połowie XVII wieku, Sobótka, Vol. 30, no 2, 1975: 234-235.

105 Polskie ustawy i artykuły wojskowe od XV do XVIII wieku, S. Kutrzeba (ed.), Polska Akademia Umiejętności, Kraków, 1937: 190 (Art. 34, 37).

106 J. Teodorczyk, Bitwa pod Gniewem (22 IX - 29 IX - 1 X 1626). Pierwsza porażka husarii, Studia i Materiały do Historii Wojskowości”, Vol. 12, 1966: 165 (in Polish). 
like in the other parts of Europe. In order to increase the determination of the troops, all soldiers were authorized to administer justice. This was to involve a possibility of wounding or even killing the escaping soldier. This solution existed in articles of war throughout Europe, in particular in the areas with landsknechts. In the Crown appropriate regulations emerged in the mid- $16^{\text {th }}$ century and were perfectly adopted existing till the end of the Commonwealth. Only from the mid-1 $18^{\text {th }}$ century on, those solutions were abandoned, to be restored during the Kościuszko Insurrection (1794). The Grand Duchy of Lithuania adopted the solutions considerably later and they remained in force incessantly from 1635 onwards. The instrument passed into the hands of soldiers, which enabled them to apply justice during a battle, which certainly promoted bravery and courage, was in contradiction with the rules of absolute obedience and hierarchical order. For this reason, armies in European states gradually revoked the powers vested in "free soldiers", introducing the precept of executing judicial sentences, or else changing the powers into a precept and vesting this thankless obligation in selected officers and appointed soldiers.

A characteristic quality of the Polish-Lithuanian cavalry units was a very small number of officers. The unit was commanded by a rotmistrz (lieutenant) standing at the front of the unit; in its centre was a chorąży. The cavalry was formed in shallow lines. In the modern period there were 5 to 2 lines, with a trend to shallow them in the subsequent decades. As a rule, in the first line stood full-fledged soldiers or towarzyszes, whereas pocztowys were placed in the depth of the formation. In order to prevent chaos during a battle and dispersion of the unit (as a result of both, stress connected with the fight, as well as during a chase and desire for loots) a special category was created: supervising towarzyszes. It was probably formed as early as the 1540 s and existed successfully until the first half of the $18^{\text {th }}$ century. For this purpose the officers highest in hierarchy were appointed. This way of forming the troops, along with legal solutions, certainly did not guarantee victory, but enhanced determination and morale of the unit. To illustrate it, it is worth referring to a weird attempt at military reforms during the Great Northern War, which involved reversing the lines. Perhaps the increasingly powerful fire of the musketeers made the towarzyszes and their rotmistrzes change the formation. They placed the pocztowys in the first line, and in the second (simultaneously the last) stood the towarzyszes and their commander supervising the lines from behind. In battlefields this formation proved worthless, the evidence of which was the Battle of Kryżbork (Jakobstadt) in $1704^{107}$. In the light of Aleksander Mackiewicz's account, the Hussar Rota of Hetman Michał Wiśniowiecki was formed. As soon as the first Swedish salvo hit, the unit broke and scattered, and followed by escaping nearby cavalry rotas. However, the other hussar rota of Karol Radziwiłł was formed up according to the old custom, with a supervising towarzysz placed at the rear. This unit withstood three salvos and effectively attacked the enemy. During the battle the supervising towarzysz of the rota, Józef Swida, was shot once in the leg and was wounded in the head, and his horse suffered nine injuries ${ }^{108}$. The battlefield determinations of both hussar units were completely different, as different was their formation.

\section{Summary}

The crime of desertion from a battlefield was the most characteristic construction of military law in modern Europe. In the period of "free soldiers" (landsknechts) developed powers granted to soldiers allowing them to wound and kill fugitives from a battlefield. The solution was adopted in the Crown in the mid- $16^{\text {th }}$ century and in the Grand Duchy of Lithuania in the 1630s. Along with imposing strict supervision over mercenaries in Europe, and then transforming them in a standing army of professional soldiers, the solution fades away. In the Commonwealth it lasts until the mid $-18^{\text {th }}$ century and its renaissance, in a considerable modified formula, occurs during the Kościuszko Insurrection (1794).

The norm evoked many controversies; it propagated fortitude and bravery, but was against the rule of obedience and absolute submission to military authorities (officers and courts). The combat methods

107 K. Kościelniak, Polish accounts of the participation of the Lithuanian armed forces in the battle of Kryżbork/Jakobstadt, Open Political Science, Vol. 2, 2019: 174-180.

108 E. Tyszkiewicz, Listy o Szwecji, Vol. 2, Nakładem i drukiem Józefa Zawadzkiego, Wilno, 1846: 218-220. 
in the Commonwealth resulted in reinforcement of the existent powers through organizing the so-called supervising towarzyszes. The formation was to secure stronger determination during the fight and provided greater chances of controlling the riders during the battle.

\section{Bibliography}

\section{Archival Material}

Archiwum Główne Akt Dawnych (Warsaw), Archiwum Radziwiłłów II: 1154.

Archiwum Główne Akt Dawnych (Warsaw), Archiwum Radziwiłłów VII: 5, 260, 712.

Archiwum Narodowe w Krakowie (Crakow), Archiwum Podhoreckie II: 39, 171.

Biblioteka PAN w Kórniku (Kórnik), 659.

Biblioteka PAU i PAN (Crakow), 974.

Riksarkivet (Stockholm), Militaria: 903, 904.

Rossijskaâ Nacional'naâ Biblioteka (Sankt Petersburg), Otdel rukopisej, Avtografi Dubravskago (Fond 971), 321/1, No 1; 321/2, No 243, 244.

\section{Printed sources}

An Appendix Of the Lavves, Articles, \& Ordinances, established for Marshall Discipline..., Hagh, 1643.

Articuls-Brieff Darnach Deß Durchleuchtigsten Fürsten und Herrn Herrn Carl Ludwigen Pfaltzgrafen, [Friederichsburg, 1674] (in German).

Brodowski S., Corpus iuris militaris Polonicum, Drukarnia Nieboszczyka Preussa, Elbląg 1753 (in German and Polish).

Churfürstliches Brandenburgisches Kriegsrecht oder Articuls-Brieff Brandenburgisches Kriegsrecht oder Articuls-Brieff, in Corpus Constitutionum Marchicarum, Vol. 3: Von Kriegs-Sachen, betreffend den Militair-Process, Disciplin, Straffen..., Berlin-Halle, 1737 (in German).

Corpus iuris militaris des heiligen Römischen Reichs, J. C. Lüning (ed.), Leipzig, 1723 (in German).

Diariusze relacje, listy i akta z lat 1576-1586, I. Polkowski (ed.), Polska Akademia Umiejętności, Kraków, 1887.

Die Kriegsordnung des Markgrafen zu Brandenburg Ansbach und Herzogs zu Preussen Albrecht des Älteren: Königsberg 1555, H.J. Bömelburg, B. Chiari, M. Thomae (ed.), Archiv Verlag, Braunschweig, 2006 (in Polish and German).

Frauenholz E. von, Das Heerwesen in der Zeit des Dreissigjährigen Krieges, Vol. 3, No 1: Das Söldnertum, C.H. Beck'sche Verlagsbuchhandlung, München, 1938.

Fredro J.M., O porządku wojennym i o pospolitem ruszeniu, ed. K. Pollak, Wydawnictwo Biblioteki Polskiej, Sanok, 1856: $34-36$ (in Polish).

Gheyn J. de, Wapenhandelinghe von roers, musquetten ende spiessen ..., 's-Gravenhage, 1607 (in Dutch).

Instrukcje i artykuły hetmańskie Jana Tarnowskiego, Z. Spieralski (ed.), Studia i Materiały do Historii Wojskowości, Vol. 36, 1994: 271-308 (in Polish).

Jabłonowski J.S., Pamiętniki, ed. A. Bielowski, Zakład Narodowy im. Ossolińskich, Lwów, 1862 (in Polish).

Kiliński J., Pamiętniki, S. Herbst (ed.), Państwowy Instytut Wydawniczy, Warszawa, 1958 (in Polish).

Kochowski W., Lata potopu 1655-1657, A. Kersten (ed.), L. Kukulski (transl.), Ministerstwa Obrony Narodowej, Warszawa, 1966 (in Polish).

Kodeks wojskowy Piotra I z 1716 roku, ed. P. Krokosz, K. Łopatecki, Napoleon V, Kraków-Oświęcim, 2016 (in Polish).

Konfederacja Barska. Wybór tekstów, W. Konopczyński (ed.), Krakowska Spółka Wydawnicza, Kraków, 1928 (in Polish).

Krijgz articlar, som fordom then stormechtigste furste och herre, herr Gustaff Adolph, then andre och store Sweriges, Goethes och Wendes, Konung storfurste til Finland, Stockholm, 1621 (in Sweden).

Księcia Krzysztofa Radziwiłła sprawy wojenne i polityczne 1621-1622, Drukarnia L. Martinet, Paryż, 1859. 
Londoño S. de, Rozważania o sposobie przywrócenia dyscypliny wojskowej do jej klasycznej i doskonalszej postaci, P. Szadkowski (transl. and ed.), Napoleon V, Oświęcim, 2016 (in Polish).

[Lubomirski H.], Ordynacja hetmańska, in J. Wojtasik, Ordynacja hetmańska dotycząca taktyki wojsk polskich z początku XVIII w., Studia i Materiały do Historii Wojskowości, Vol. 6, No 1, 1960: $290-292$ (in Polish).

Łaski S., Prace naukowe i dyplomatyczne, wyd. M. Malinowski, Nakładem i Drukiem Józefa Zawadzkiego, Wilno, 1864: 75 (in Polish).

Meynert H., Geschichte der k. k. österreichischen Armee, ihrer Heranbildung und Organisation, Bd. II, C. Gerold \& sohn, Wien, 1852 (in German).

Pamiętniki o Koniecpolskich. Przyczynek do dziejów polskich XVII wieku, ed. S. Przyłęcki, Nakładem Leona Rzewuskiego, Lwów, 1842 (in Polish).

Piotrowski J., Dziennik wyprawy Stefana Batorego pod Psków, A. Czuczyński (ed.), Nakładem Księgarni Spółki Wydawniczej Polskiej, Kraków, 1894 (in Polish).

Polskie ustawy i artykuły wojskowe od XV do XVIII wieku, S. Kutrzeba(ed.), Polska Akademia Umiejętności, Kraków, 1937 (in Latin and Polish).

Relacje wojenne z pierwszych lat walk polsko-kozackich powstania Bohdana Chmielnickiego okresu „Ogniem i Mieczem” (1648-1651), ed. M. Nagielski, Viking Books, Warszawa, 1999 (in Polish).

Sammlung der württembergischen Gesetze: Kriegs-Gesetze, Theil 1: Enthaltend die Kriegs-Gesetze von 1360 bis 1800, S.F.J. von Kapff (ed.), Tübingen, 1849 (in German).

Schwedisches Kriegs-Recht oder Articuls-Brieff desz ... Herrns Gustaff Adolffs ..., Heylbrunn, 1632, (in German).

Starowolski S., Prawy rycerz, ed. K. J. Turowski, Wydawnictwo Biblioteki Polskiej, Kraków, 1858 (in Polish). Tyszkiewicz E., Listy o Szwecji, Vol. II, Nakładem i drukiem Józefa Zawadzkiego, Wilno, 1846 (in Polish).

Wimmer J., Błażeja Lipowskiego pierwszy polski regulamin piechoty, Studia i Materiały do Historii Wojskowości, Vol. 20: 1976: 335-357 (in Polish).

Winthrop W., Military Law and Precedents, Government Printing Office, Washington, 1920.

\section{General bibliography}

Anners E., Den karolinska militärstraffrätten och Peter den stores krigsartiklar, Almqvist \& Wiksell, Uppsala, 1961 (in Sweden).

Ashburner W., The Byzantine Mutiny Act, The Journal of Hellenic Studies, Vol. 46, 1926: 80-109.

Błaszczyk G., Ustawy i artykuły wojskowe Polski i Litwy do 1569 roku, Studia i Materiały do Historii Wojskowości, Vol. 39, 1998: 29-75 (in Polish).

Bobrovskiy P.O., Veyde Adam Adamovich. Odin iz glavnykh sotrudnikov Petra Velikogo i yego voyennyy ustav1698 goda. (Istoriko-yuridicheskoye issledovaniye), tip. Imp. un-ta, Kazan', 1887 (in Russian).

Boeft J. Den, Drijvers J.W., Hengst D. Den, Teitler H.C., Philological and Historical Commentary on Ammianus Marcellinus: XXIV, Brill, Liden-Boston-Köln, 2002.

Bołdyrew A., Piechota zaciężna w Polsce w pierwszej połowie XVI wieku, Wydawnictwo Neriton, Warszawa, 2011 (in Polish).

Bołdyrew A., The Bow in the Borderland in the 16th Century, Fasciculi Archeologiae Historicae, Vol. 30 , 2017: 11-17.

Bomanowski B., Współdziałanie wojsk Rzeczypospolitej Obojga Narodów w pierwszym etapie walk kampanii cudnowskiej, Acta Universitatis Lodziensis. Folia Historica, Vol. 95, 2015: 65-87 (in Polish).

Brand C.E., Roman Military Law, University of Texas Press, Austin-London, 1968.

Cibicki M., Taktyka jazdy staropolskiej, Przegląd Kawaleryjski, Vol. 4, No 2, 1927: 212-222 (in Polish).

Ciesielski T., Armia koronna w czasach Augusta III, Wydawnictwo DiG, Warszawa, 2009 (in Polish).

Ciesielski T., Samuel Brodowski - kodyfikator prawa wojskowego w czasach panowania Augusta III, in Historia testis temporum, lux veritatis vita memoriae, nuntia vetustatis. Księga Jubileuszowa dedykowana Profesorowi Włodzimierzowi Kaczorowskiemu, E. Kozerska, M. Maciejewski, P. Stec (ed.), Wydawnictwo Uniwersytetu Opolskiego, Opole, 2015: 399-420 (in Polish). 
Davies B.L., Warfare, State and Society on the Black Sea Steppe, 1500-1700, Routledge, London - New York, 2007.

Dybaś B., Fortece Rzeczypospolitej. Studium z dziejów budowy fortyfikacji stałych w państwie polskolitewski w XVII wieku, Towarzystwo Naukowe w Toruniu, Torun, 1998 (in Polish).

Englund P., Die Verwüstung Deutschlands: eine Geschichte des Dreissigjährigen Krieges, Klett-Cotta, Stuttgart, 1998 (in German).

Englund P., Lata wojen, W. Łygaś (transl.), Finna Oficyna Wydawnicza, Gdańsk, 2003 (in Polish).

Florek P., Z taktyki wojsk polskich podczas działań wojennych w Moskwie 1608-1611, Czasy Nowożytne, Vol. 4, 1998: 167-187 (in Polish).

Frost R. I., The Polish-Lithuanian Commonwealth and the „Military Revolution”, in Poland and Europe: Historical Dimensions, ed. M.B. Biskupski, J.S. Pula, Columbia University Press, New York, 1994: 19-47.

Frost R.I., Potop a teoria rewolucji militarnej, in Rzeczpospolita w latach potopu, ed. J. Muszyńska, J. Wijaczka, Wyższa Szkoła Pedagogiczna im. Jana Kochanowskiego, Kielce, 1996: 147-165 (in Polish).

Gentles I., The English Revolution and the Wars in the Three Kingdoms, 1638-1652, Pearson Education Limited, Harlow, 2007.

Gervase P., Longbow and Hackbutt: Weapons Technology and Technology Transfer in Early Modern England, Technology and Culture, Vol. 40, No 3, 1999: 576-593.

Girvés M.V., Violación del Sacramentum y Crimen maiestatis: la cobardía en el ejército de Roma, Habis, Vol. 28 1997: 167-177 (in Spain).

Hoogendoorn K., Bibliography of the Exact Sciences in the Low Countries from ca. 1470 to the Golden Age (1700), Brill, Leiden-Boston 2018.

Jung J. H., Die Rechtsstellung der römischen Soldaten. Ihre Entwicklung von den Anfängen Roms bis auf Diokletian, in Aufstieg und Niedergang der römischen Welt, Bd. II/14, H. Temporini (ed.), Berlin 1982, s. 882-1013 (in German).

Kamiński J., Historia sądownictwa wojskowego w dawnej Polsce, Towarzystwa Wiedzy Wojskowej, Warszawa, 1928 (in Polish).

Karwin J., Pomianowski E., Rutkowski S., Z dziejów wychowania wojskowego w Polsce od początku państwa polskiego do 1939 roku, Wydawnictwo Ministerstwo Obrony Narodowej, Warszawa, 1969 (in Polish).

Koranyi K., Żołnierz najemny, a żołnierz zaciężny, Czasopismo Prawno-Historyczne, Vol. 1, 1948: 105-108 (in Polish).

Kościelniak K., Polish accounts of the participation of the Lithuanian armed forces in the battle of Kryżbork/Jakobstadt, Open Political Science, Vol. 2, 2019: 174-180.

Kotarski H., Wojsko polsko-litewskie podczas wojny inflanckiej 1576-1582. Sprawy organizacyjne, Vol. III, Studia i Materiały do Historii Wojskowości, Vol. 17, 1971: 81-151, (in Polish).

Kott A., Perconti P., Leslie N., Discovering a Regularity: the Case of An 800-year Law of Advances in Small-Arms Technologies, https://arxiv.org/pdf/1908.03435 (access: 8.01.2020).

Krawczuk W., Wojna szarpana doby „potopu” - doświadczenia szwedzkie, Zeszyty Naukowe Uniwersytetu Jagiellońskiego. Prace Historyczne, Vol. 143, No 4, 2016: $737-742$ (in Polish).

Krenn P., Kalaus P., Hall B., Material Culture and Military History: Test-Firing Early Modern Small Arms, Material History Review, Vol. 42, 1995: 101-109.

Kuleczka G., Studia nad rzymskim wojskowym prawem karnym, Uniwersytet im. Adama Mickiewicza, Poznań, 1974 (in Polish).

Kupisz D., Wojska powiatowe samorządów Małopolskii Rusi Czerwonej wlatach 1572-1717, Wydawnictwo Uniwersytetu Marii Curie-Skłodowskiej, Lublin, 2008 (in Polish).

Kupisz D., Wyprawy żołnierza łanowego w Koronie w czasach Jana Kazimierza, Wydawnictwo Sejmowe, Warszawa, 2018 (in Polish).

Laskowski O., Odrębności staropolskiej sztuki wojennej, Przegląd Historyczno-Wojskowy, Vol. 6, No 1, 1935: 1-35 (in Polish).

Lynn J.A., Giant of the Grand Siècle. The French army, 1610-1715, Cambridge University Press, Cambridge, 1997. 
Łopatecki K., „Disciplina militaris” w wojskach Rzeczypospolitej do połowy XVII wieku, Instytut Badań nad Dziedzictwem Kulturowym Rzeczypospolitej, Białystok, 2012 (in Polish).

Łopatecki K., Artykuły wojskowe autoramentu cudzoziemskiego Władysława IV - okoliczności powstania i ich charakterystyka, Zeszyty Prawnicze UKSW, Vol. 11, No 2, 2011: 235-255 (in Polish).

Łopatecki K., Pierwszy poetycki traktat wojskowy z mapą - Jana Kunowskiego Odsiecz smoleńska. Wykorzystanie kartografii w działaniach operacyjnych (1616-1617), Rocznik Lituanistyczny, Vol. 4, 2018: $41-75$ (in Polish).

Łopatecki K., Przestępstwo ucieczki z pola bitwy w Rzeczypospolitej szlacheckiej - z badań nad karą śmierci wymierzaną $w$ trybie pozasądowym, in Culpa et poena. $Z$ dziejów prawa karnego, $M$. Mikuła (ed.), Wydawnictwo Uniwersytetu Jagiellońskiego, Kraków, 2009: 189-203 (in Polish).

Majewski A.A., Szarża husarska pod Warszawą 29 lipca 1656 roku, Przegląd Historyczno-Wojskowy, Vol. 13, No 3, 2012: 167-174 (in Polish).

Majewski R., Z problematyki walk z Tatarami w pierwszej połowie XVII wieku, Sobótka, Vol. 30, no 2, 1975: 231-241.

Marshall H., Military Miscellany, comprehending a History of the Recruiting of the Army, Military Punishments, John Murray, Albemarle Street, London, 1846.

McLachlan S., Medieval Handgonnes: The first black powder infantry weapons, Bloomsbury Publishing, Oxford, 2010.

Nagielski M., Chorągwie dworzańskie Jana Kazimierza podczas dwóch batalii kozackich 1649-1651, in Gospodarka, ludzie, władza: studia historyczne ofiarowane Juliuszowi Łukasiewiczowi w 75 rocznicę urodzin, M. Kopczyński, A. Mączak (ed.), Wydawnictwo Krupiński i S-ka, Warszawa, 1998 (in Polish).

Nimwegen O. v., The Transformation of Army Organization in Early-Modern Western Europe, c. 15001789, in European Warfare, 1350-1750, F. Tallet (ed.), Cambridge University Press, Cambridge, 2001: 159-180.

Nowak T.M., Wimmer J., Historia oręża polskiego 963-1795, Wiedza Powszechna, Warszawa, 1981 (in Polish).

Organiściak W., Kara śmierci w prawie wojskowym Rzeczypospolitej szlacheckiej od XVI do XVIII wieku, Problemy Prawa Karnego, Vol. 20, 1994: 79-93 (in Polish).

Organiściak W., Kodeksy wojskowe w Polsce roku 1775, Wydawnictwo Uniwersytetu Śląskiego, 2001 (in Polish).

Organiściak W., Wpływ idei humanitarnych na kodyfikację prawa wojskowego Rzeczypospolitej w 1775 roku, Problemy Prawa Karnego, Vol. 22, 1997: 114-132 (in Polish).

Organiściak W., Ze studiów nad reformą prawa wojskowego za czasów Stanisława Augusta, Czasopismo Prawno-Historyczne, Vol. 53, No 1, 2001: 177-200 (in Polish).

Ostrowski D., The Replacement of the Composite Reflex Bow by Firearms in the Muscovite Cavalry, Kritika: Explorations in Russian and Eurasian History, Vol. 11, No 3, 2010: 513-534.

Parker G., Od domu orańskiego do domu Bushów: czterysta lat „rewolucji militarnej”, Przegląd Historyczny, Vol. 96, No 2, 1996: 217-243 (in Polish).

Péter V., De re militari (A katonai jogról - forráselemzés), in Acta Universitatis Szegediensis: acta juridica et politica, Vol. 57, No 11, 1999: 3-23 (in Hungary).

Plewczyński M., Skład chorągwi jazdy koronnej w latach 1501-1572, Studia i Materiały do Historii Wojskowości, Vol. 35, 1993: 33-56 (in Polish).

Polskie tradycje wojskowe, t. I: Tradycje walk obronny z najazdami Niemców, Krzyżaków, Szwedów, Turków i Tatarów X-XVII, ed. J. Sikorski, Wydawnictwo Ministerstwa Obrony Narodowej, Warszawa, 1990 (in Polish).

Refshauge W.F., A note on physical properties of musket fire, Journal of Conflict Archaeology, Vol. 10, No 3, 2015: 149-153.

Roberts M., The Military Revolution, 1560-1660, in The Military Revolution Debate: Readings on the Military Transformation on Early Modern Europe, C. J. Rogers (ed.), Westview Press, Boulder 1995: 13-36.

Rogers C.J., Tactics and the face of battle, in European Warfare, 1350-1750, ed. F. Tallett, D.J.B. Trim, Cambridge University Press, Cambridge, 2010: 203-235.

Różycki Ł., Mauricii Strategicon. Praktyczny podręcznik wojskowy i dzieło antykwaryczne, Instytut Historii UAM, Poznań, 2015 (in Polish) 
Schwager T, Militärtheorie im Späthumanismus: Kulturtransfer taktischer und strategischer Theorien in den Niederlanden und Frankreich (1590-1660), De Gruyter, Berlin, 2012 (in German).

Sikora R., Fenomen husarii, Dom Wydawniczy DUET, Torun, 2003 (in Polish).

Swart E., From „Landsknecht” to Soldier: The Low German Foot Soldiers of the Low Countries in the Second Half of the Sixteenth Century, International Review of Social History, Vol. 51, No 1, 2006: 75-92.

Szadkowski P., Staropolskie i hiszpańskie piśmiennictwo wojskowe XVI wieku w kontekście teorii rewolucji militarnej. Próba porównania, Kwartalnik Historyczny, Vol. 125, No 3, 2018: 597-631.

Tallet F., War and Society in Early-Modern Europe, 1495-1715, Taylor \& Francis, London-New York, 2003. Teodorczyk J., Bitwa pod Gniewem (22 IX - 29 IX - 1 X 1626). Pierwsza porażka husarii, Studia i Materiały do Historii Wojskowości”, Vol. 12, 1966: 71-172 (in Polish)

Urwanowicz J., Wojsko Rzeczypospolitej wobec polityki (na tle postaw armii europejskich), in Dziedzictwo pierwszej Rzeczypospolitej w doświadczeniu politycznym Polski i Europy, ed. J. Ekes, Wydział Studiów Politycznych WSB-NLU w Nowym Sączu, Nowy Sącz, 2005: $25-38$ (in Polish).

Urwanowicz J., Wojskowe „sejmiki”. Koła w wojsku Rzeczypospolitej XVI-XVIII wieku, Wydawnictwo Uniwersytetu w Białymstoku, Białystok, 1996 (in Polish).

Wagner M., Podoficerowie armii koronnej w drugiej połowie XVII w., Studia i Materiały do Historii Wojskowości, Vol. 34, 1992: 67-100 (in Polish).

Walker S.J., Arms and the Man: Constructing the Soldier in Jacques de Gheyn’s „Wapenhandelinghe”, Netherlands Yearbook for History of Art, Vol. 58, 2007-2008: 138-161.

Wojtasik J., Wojna szarpana Stefana Czarnieckiego w dobie potopu szwedzkiego (1655-1660), in Z dziejów stosunków Rzeczypospolitej Obojga Narodów ze Szwecją w XVII wieku, M. Nagielski (ed.), Wydawnictwo DiG, Warszawa, 2007: 183-200.

Wojtasik J., Ordynacja hetmańska dotycząca taktyki wojsk polskich z początku XVIII w., Studia i Materiały do Historii Wojskowości, Vol. 6, No 1, 1960: 288-290 (in Polish). 